\title{
Some biolochemical and histopathological effects of different oral doses Ochratoxin A in male rats
}

\section{Duraid A.Abbas ${ }^{1}$, Mohammed K.Faraj ${ }^{1}$ and Abbas Razzaq Abed ${ }^{2}$}

1-College of Veterinary Medicine, Baghdad University. 2- Foundation of technical education, Technical Institute Babil. Iraq .

\section{Summary}

The present study was carried out to investigate the effects of Ochratoxin A (OTA) on the serum activity of AST, ALT and ALP, Glutathione (GSH) and liver, kidney and spleen histopathology .Twenty male rats divided equally into three treated groups dosed orally and daily with OTA doses (70, 140 and $210 \mu \mathrm{g} / \mathrm{kg}$ ) for 20 day representing T1, T2 and T3 groups and the fourth group dosed daily with distilled water considered as control one. Biochemical result showed elevation in AST and ALT activity and decrease in ALP enzyme activity and GSH serum concentration of treated serum groups at 10 and 20 days of exposure to ochratoxin A these changes positively were proportional with increase OTA doses (dose dependent). Histopathological changes were noticed in liver, kidney and spleen of all treated groups including (necrosis, congestion, and infiltration of inflammatory cells and vacuolation of cytoplasm). The severities of these lesions are in dose dependent manner.

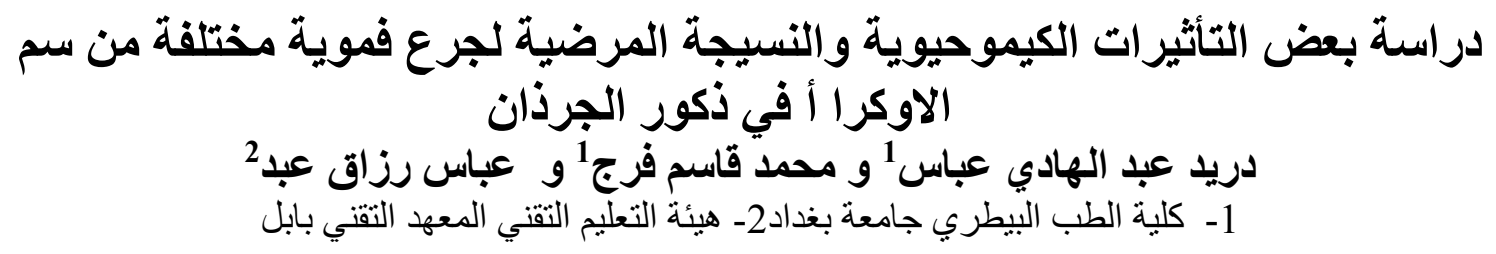

\section{الخلاصة}

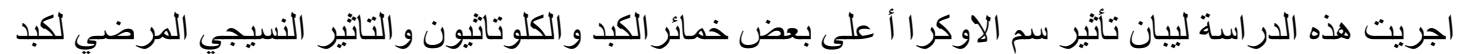

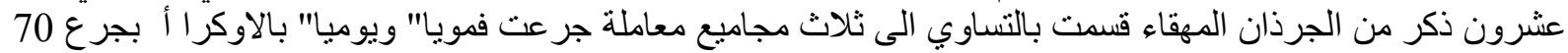

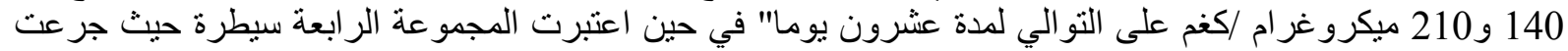

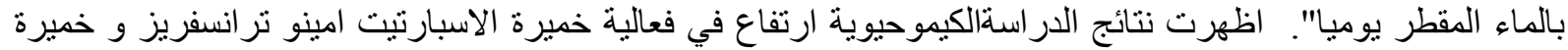

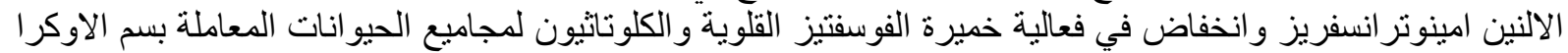

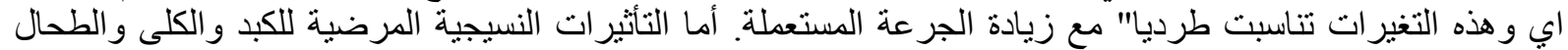

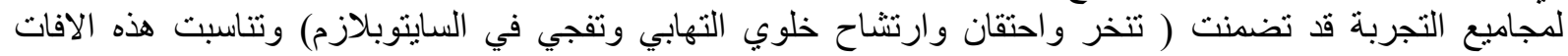

\section{Introduction}

Ochratoxin A (OTA) is a mycotoxin produced by several species of Aspergillus and Penicillium fungi that structurally consists of a para-chlorophenolic group containing a dihydroisocoumarin moiety that is amide-linked to L-phenylalanine (1) OTA is detected worldwide in various foods and feed sources.OTA was first discovered in 1965 as a fungal metabolite that was toxic to animals (2). It is a potent teratogen and hepatotoxin and has been classified as a possible carcinogen for humans $(3,4)$ because it forms DNA adducts $(5)$. There is a correlation between chronic interstitial nephritis and high exposure to OTA (6), and an immunomodulatory effect of OTA on a human monocyte/macrophage cell line has been established (7). OTA may cause the human disease Balkan Endemic nephropathy, but this connection has not yet been proven (8).

OTA act by inhibition of protein synthesis and inhibition of mitochondrial respiration and causing cellular oxidative change (9). The contribution of metabolites in OTA genotoxicity and carcinogenicity is still unclear.OTA is absorbed from the stomach, metabolised into the non-toxic metabolite ochratoxin $\alpha$, extensive plasma protein binding with t1 12840 h (35 day), excretion both biliary excretion and renal excretion play an important 
role in the plasma clearance of OTA can be related to its molecular weight of 403.8 also the OTA have ability to placental and lactational transfer (10). Some Studies in rodents suggest that OTA crosses the blood brain barrier (11). In addition since humans and animals are likely to be simultaneously exposed to several ochratoxin A by different routes, so it consider one of the serious hazard to animal and human public health (12). The Aim of study was the effect of some serum biochemical marker and histological toxic in organs of male rats treated with different OTA doses.

\section{Material and methods}

Subacute study was performed in which 20 male Albino rats weight 150-200 gm were divided equally into four groups one control dosed orally with distilled water while the other three groups dosed orally with OTA at 70,140 and $210 \mu \mathrm{g} / \mathrm{kg} / \mathrm{day}$ for twenty days representing T1, T2 and T3 respectively.The rat groups were placed in a special housing room (13) belongs to the department of physiology and pharmacology/College of Veterinary Medicine. Blood was collected at 0,10 and 20 days of experimental periods for biochemical tests. Animals were anesthetized by I.M. injection of ketamine at $90 \mathrm{mg} / \mathrm{kg} \mathrm{B.W}$ and Xylazine at $40 \mathrm{mg} / \mathrm{kg} \mathrm{B.W}$. Blood samples were obtained via cardiac puncture technique from each anesthetized animals. Determination of Aspartate and Alanine aminotransferase activities by Colorimetric method for determination of AST and ALT according to (14). Determination of alkaline phosphatase activity by Colorimetric determination alkaline phosphatase activity was achieved according to (15). Determination of Serum Reduced Glutathione Concentration (GSH). And Determination of serum glutathione (GSH) according to the method by (16).

At the end of experiment all animals groups were scarified by injection of air in the heart .The livers, kidneys and spleen were dissected and examined grossly then were fixed by $10 \%$ neutral formalin buffer solution, till the preparation of histological sections. Tissues were embedded in Paraffin and several tissue sections were prepared that stained with Hematoxylin - Eosin stain for histological examination according to (17).

Statistical analysis was conducted according to SPSS version 13.00 two ways ANOVA was used to assess the significance of changes between experimental groups and periods. The data were expressed as Mean \pm Standard Errors (SE) and a P-value $\leq 0.05$ was considered as statistically significant.LSD multiple range test was carried out to test the significance levels among means of treatments (18).

\section{I-Biochemical effect}

\section{Results}

\section{1-Aspartate aminotransferase (AST)}

The results of AST (I.U/ml) are listed in table (1) showed that there was no significant differences between T2 and T3 enzyme levels after 10 days of OTA treatment while they were significantly higher than $\mathrm{T} 1$ result. All treated groups showed significant increase $(\mathrm{P}<0.05)$ enzyme levels in comparison with control groups in dose dependent manner.

Nearly same pattern was noticed after 20 days results in which both $\mathrm{T} 1$ and $\mathrm{T} 2$ showed no significant difference but they are significant less than $\mathrm{T} 3$ enzyme levels at $(\mathrm{P}<0.05)$.

All treated groups showed significant increase $(\mathrm{P}<0.05)$ in comparison with control group in dose dependent manner. Between periods results showed significant increase in the enzyme levels of each treated group after 10 and 20 days of OTA administration $(\mathrm{P} \leq 0.05)$, in comparison with zero time but not significant between them .Control group show no change in enzyme level during the course of experiment. 
Table (1): AST (I.U/ml) in rats serum of different experimental groups dosed orally with ochratoxin A at different doses and periods.

\begin{tabular}{|c|c|c|c|}
\hline Period & $\begin{array}{l}\text { Zero day } \\
\text { treatment }\end{array}$ & $\begin{array}{l}\text { After } 10 \text { days } \\
\text { Treatment }\end{array}$ & $\begin{array}{l}\text { After } 20 \text { days } \\
\text { treatment }\end{array}$ \\
\hline Control & $70.20 \pm 1.800$ & $71.60 \pm 1.36$ & $71.60 \pm 2.03$ \\
\hline & A $\quad$ a & A $\quad$ a & A $\quad$ a \\
\hline $\mathrm{T} 170 \mu \mathrm{g} / \mathrm{Kg}$ & $72.00 \pm 2.44$ & $77.60 \pm 0.48$ & $80.00 \pm 1.00$ \\
\hline & A $\quad \mathrm{a}$ & B $\quad$ b & B $\quad$ c \\
\hline $\mathrm{T} 2140$ & $72.20 \pm 2.11$ & $81.40 \pm 1.32$ & $83.70 \pm 1.22$ \\
\hline$\mu \mathrm{g} / \mathrm{Kg}$ & A $\quad \mathrm{a}$ & $\mathrm{C} \quad \mathrm{b}$ & B $\quad$ c \\
\hline T3210 & $71.60 \pm 1.28$ & $84.70 \pm 0.53$ & $96.00 \pm 0.89$ \\
\hline$\mu \mathrm{g} / \mathrm{Kg}$ & A $\quad \mathrm{a}$ & $\mathrm{C} \quad \mathrm{b}$ & $\mathrm{C} \quad \mathrm{c}$ \\
\hline
\end{tabular}

Values represent mean \pm S.E

Different capital letters mean significant results at $(P<0.05)$ results between different groups.

Different small letters mean significant results at $(\mathbf{P}<0.05)$ between periods.

\section{2- Alanine aminotranase (ALT)}

The results of ALT (I.U/ml) are listed in table (2) showed that there was significant increase $(\mathrm{P}<0.05)$ in the enzyme values between $\mathrm{T} 1, \mathrm{~T} 2$ and $\mathrm{T} 3$ groups at doses 70,140 and $210 \mu \mathrm{g} / \mathrm{kg}$ respectively after 10 and 20 days from orally administration of ochratoxin $\mathrm{A}$ in dose dependent manner and between each treated groups and control one. Between periods results showed significant increase in enzyme levels of each treated group after 10 and 20 days of OTA exposure $(\mathrm{P} \leq 0.05)$, in comparison with zero time .Control group showed no change in enzyme level during the course of experiment.

Table (2): ALT level (I.U/ml) in rats serum of different experimental groups dosed orally with ochratoxin A at different doses and periods.

\begin{tabular}{|c|c|c|c|}
\hline Groups & $\begin{array}{l}\text { Zero day } \\
\text { treatment }\end{array}$ & $\begin{array}{l}\text { After } 10 \text { days } \\
\text { treatment }\end{array}$ & $\begin{array}{l}\text { After } 20 \text { days } \\
\text { treatment }\end{array}$ \\
\hline & $23.20 \pm 1.24$ & $23.50 \pm 0.89$ & $24.80 \pm 0.84$ \\
\hline Control & $\mathrm{A} \quad \mathrm{a}$ & $\mathrm{A} \quad \mathrm{a}$ & $\mathrm{A} \quad \mathrm{a}$ \\
\hline T1 & $23.10 \pm 1.69$ & $29.90 \pm 0.81$ & $35.30 \pm 1.05$ \\
\hline $70 \mu \mathrm{g} / \mathrm{Kg}$ & A $\quad$ a & B $\quad b$ & $\mathrm{~B} \quad \mathrm{c}$ \\
\hline T2 & $23.50 \pm 1.07$ & $36.10 \pm 1.32$ & $41.80 \pm 1.77$ \\
\hline $140 \mu \mathrm{g} / \mathrm{Kg}$ & A $\quad \mathrm{a}$ & $\mathrm{C} \quad \mathrm{b}$ & $\mathrm{C} \quad \mathrm{c}$ \\
\hline T3 & $24.90 \pm 1.36$ & $40.90 \pm 0.99$ & $53.50 \pm 2.01$ \\
\hline $210 \mu \mathrm{g} / \mathrm{Kg}$ & A $\quad$ a & $\mathrm{D} \quad \mathrm{b}$ & $\mathrm{D} \quad \mathrm{c}$ \\
\hline
\end{tabular}

LSD group $=1.77 \quad$ LSD period $=1.53 \quad n=5$

Values represent mean \pm S.E

Different capital letters mean significant results at $(\mathbf{P}<0.05)$ results between different groups

Different small letters mean significant results at $(\mathbf{P}<0.05)$ between periods.

\section{3-Alkaline phosphatase}

The results of ALP level (I.U/ml) are listed in table (3) showed that there was significant decrease $(\mathrm{P}<0.05)$ in the enzyme values between $\mathrm{T} 1, \mathrm{~T} 2$ and $\mathrm{T} 3$ groups after 10 and 20 days from orally administration of ochratoxin $\mathrm{A}$ in dose dependent manner also between each treated group and control one. Between periods significant decrease in enzyme levels of each treated group after 10 and 20 days of OTA exposure $(\mathrm{P} \leq 0.05)$, in comparison with zero time. Control group show no change in enzyme level during the course of experiment. 
Table (3): ALP (I.U/L) in rats serum of different experimental groups dosed orally with ochratoxin $A$ at different doses and periods.

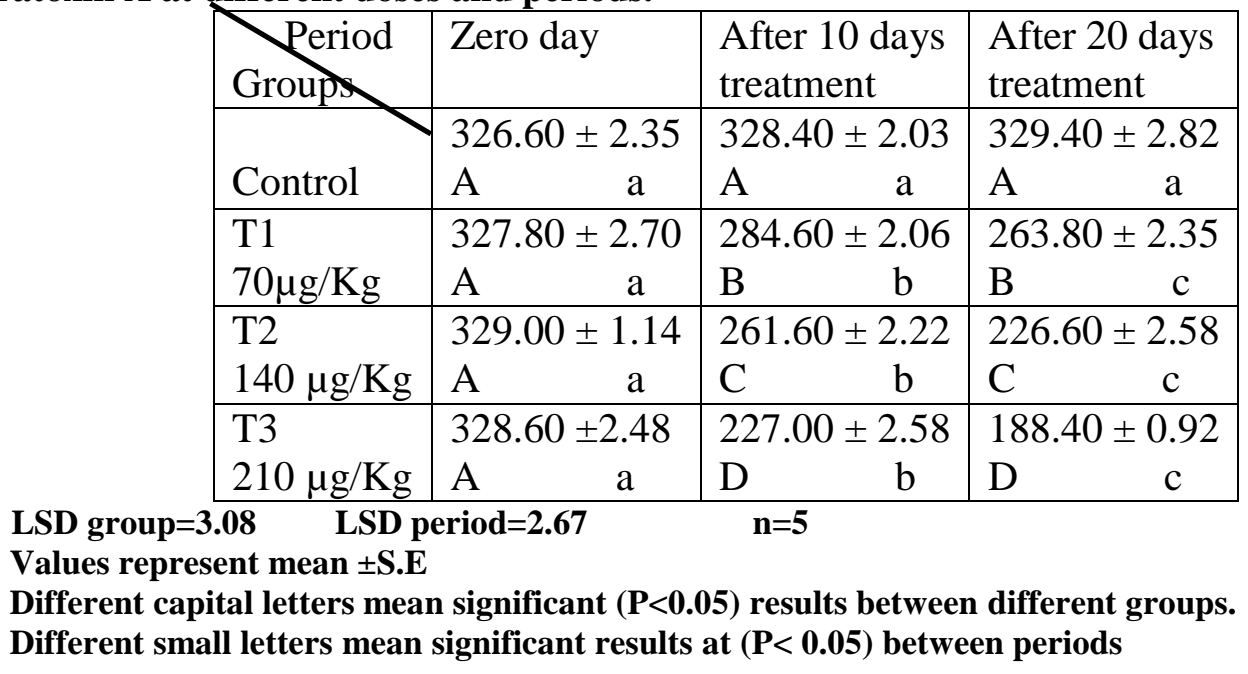

\section{4-Glutathione (GSH)}

The results of GSH value ( $\mu$ moler /L) are listed in table (4) The results showed that there was significant decrease $(\mathrm{P}<0.05)$ in the GSH values between $\mathrm{T} 1$, T2 and T3 groups at doses 70,140 and $210 \mu \mathrm{g} / \mathrm{kg}$ respectively after 10 and 20 days from orally administration of ochratoxin A and in comparison with the control group. Between periods results showed significant decrease in serum glutathion levels of each treated group after 10 and 20 days of OTA exposure $(\mathrm{P} \leq 0.05)$, in comparison with zero time .Control group show no change in GSH level during the course of experiment.

Table (4): GSH ( $\mu \mathrm{mol} / \mathrm{L})$ in rats serum of different experimental groups dosed orally with ochratoxin $A$ at different doses and periods.

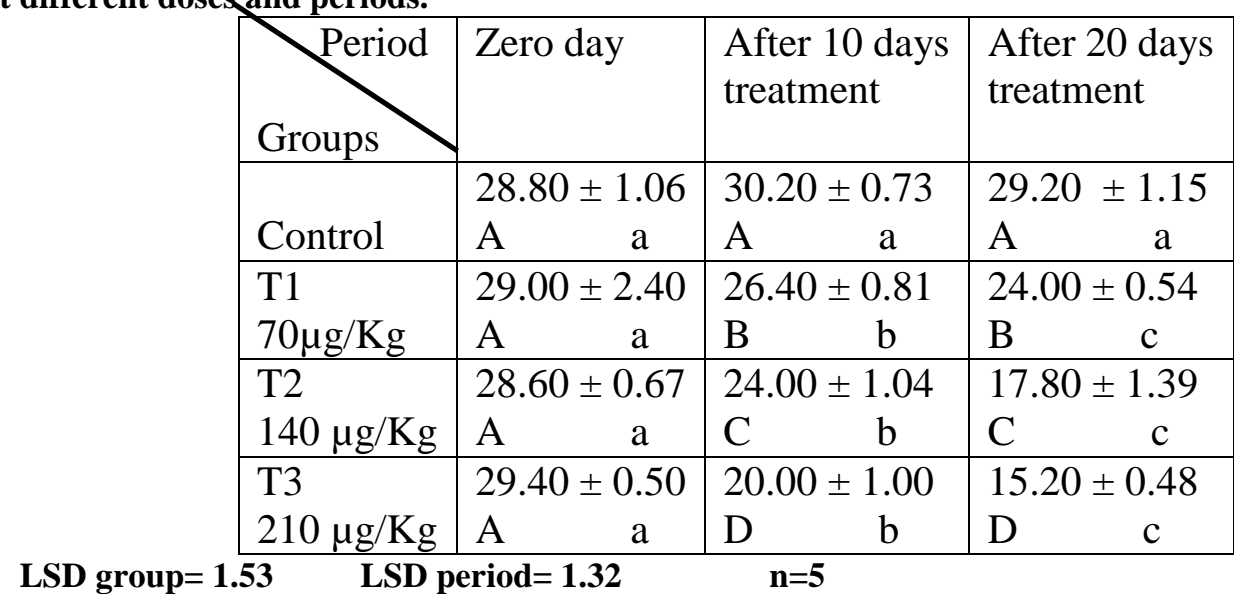

Values represent mean \pm S.E

Different capital letters mean significant results at $(\mathrm{P}<0.05)$ results between different groups.

Different small letters mean significant results at $(P<0.05)$ between periods.

\section{II- Histopathological effects}

1-Liver: There is aggregation of macrophage around the congested central veins , inflammatory cells particularly neutrophils in their lumen with aggregation of mononuclear cell in portal area around bile duct and blood vessels. The sinusoid showed dilatation and inflammatory cells infiltration, mainly lymphocyte and macrophage in their lumen, there are other lesion seen such as necrosis of hepatocyte characteristic by pyknotic with disappearance of nucleus, the severity of these histopathological changes increase with increasing OTA doses, figure(1).

2-Kidney: The microscopic section showed congestion of blood vessels between renal tubules with inflammaty cells particularly neutrophil as well as RBCs in the lumen of the 
renal tubules. Acute cellular degeneration of epithelial lining of renal tubules characterized by vacoulation of the cytoplasm, also inflammatory cells aggregation in the interstitial tissues forming small granulomatus lesion . there is increase in thickness of wall of bowman capsule due to proliferation of fibrous connective tissue and mononuclear cell infiltration, also hypoplasia of the epithelial lining cells of papillary duct and hyperatrophy of their muscle layer were seen, figure (2). The severity of these lesions were positively proportional with OTA doses.

3-Spleen : Microscopic section showed congestion of the red pulp and blood vessels with increase thickness of the muscular layer of congested blood vessels also atrophy of white pulp is seen figure (3).The severity of these histopathological changes increase with increasing OTA doses.

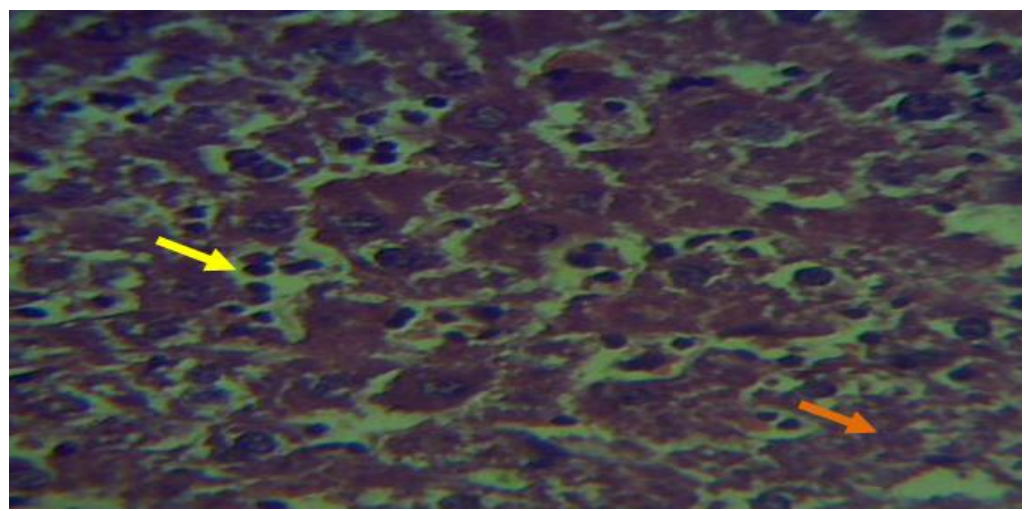

Figure (1):- Histopathological section of liver for rat after 20 days of treatment with OTA at dose $70 \mu \mathrm{g} / \mathrm{kg}$ show dilatation of sinusoid with neutrophils in their lumen $(\longrightarrow)$ as well as necrosis of hepatocyte cells $(\longrightarrow)$.

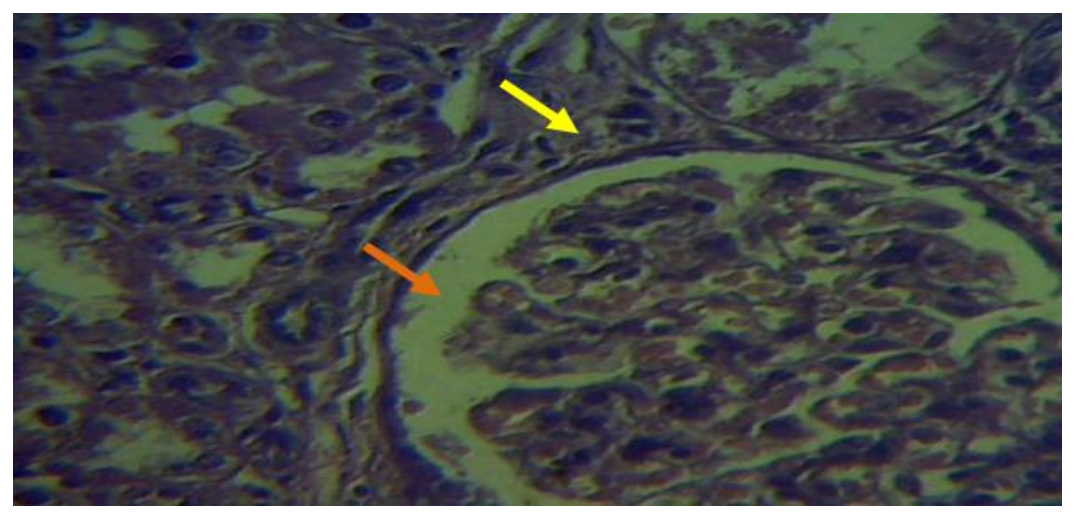

Figure (2):- Histopathological section of kidney for rat after 20 days of treatment with OTA at dose $70 \mu \mathrm{g} / \mathrm{kg}$, shows thickness of Bowman capsule( ) with dilation of Bowman space

) (H and $\mathbf{E}$ stain $40 \mathrm{X}$

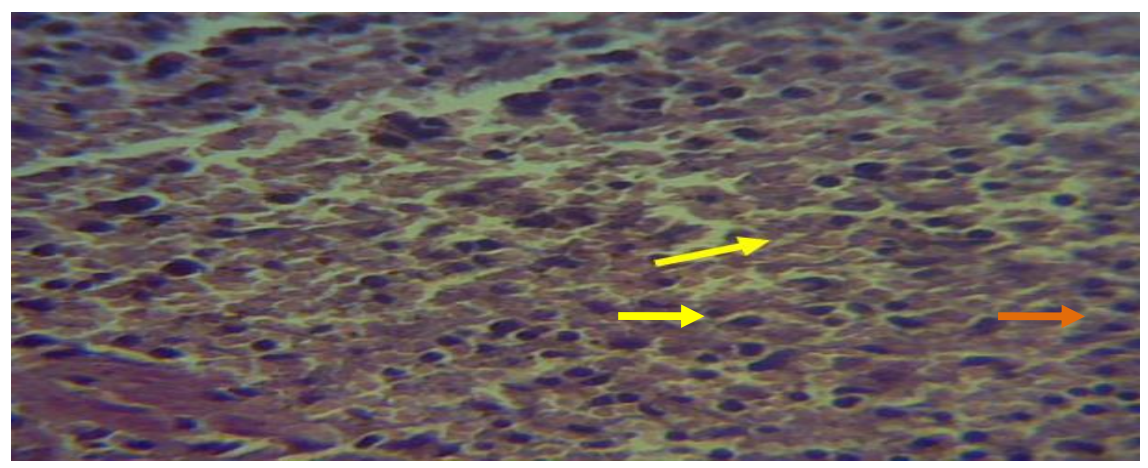

Figure (3):- Histopathological section of spleen for rat after 20 days of treatment with OTA at dose $70 \mu \mathrm{g} / \mathrm{kg}$ show congestion of red pulps and blood vessels $(\longrightarrow$ ). 
The liver, has a variety of transaminases to synthesize and break down amino acids and to interconvert energy storage molecules. The concentrations of these enzymes in the serum (the non-cellular portion of blood) are normally low. However, if the liver is damaged, the hepatocyte cell membrane becomes more permeable and some of the enzymes leak out into the blood stream. The two transaminases commonly measured are alanine transaminase (ALT) and aspartate transaminase (AST). Elevated levels are quite sensitive for liver injury, meaning that they are likely to be present if there is injury. However, they may also be elevated in other conditions. ALT is not commonly found outside the liver; AST too is most commonly found in the liver, but also in significant amounts in cardiac (heart) and skeletal muscle. In fact, measurement of these used to be part of diagnosing heart attacks (19). The results of AST and ALT serum level in our study are in agreement with the result of (20) in which ochratoxin A causes increase AST and ALT value when exposed the rats to ochratoxin A ( $2.5 \mathrm{mg} / \mathrm{kg}$ body weight) for 8 weeks by gastric intubation.

The elevated AST and ALT levels may indicate inflammation or damage to cells in the liver. Inflamed or injured liver cells leak higher than normal amounts of certain chemicals, including liver enzymes, into the bloodstream, which can result in elevated liver enzymes on blood tests. (21).This toxic effect was confirmed by the histopathological changes noticed in livers of OTA dosed rat groups in dose dependent manner.

Alkaline Phosphatases are a group of enzymes found primarily the liver (isoenzyme ALP1) and bone (isoenzyme ALP-2). There are also small amounts produced by cells lining the intestines (isoenzyme ALP-3), the placenta, and the kidney (in the proximal convoluted tubules). What is measured in the blood is the total amount of alkaline phosphatases released from these tissues into the blood. (22).

ALP results was in agreement with the result (23) in which OTA given in food for pig at doses $(0.5$ and $2.5 \mathrm{mg} / \mathrm{kg})$ for 21 days which led to lowest activity of ALP level because of the low concentration of Phosphate in their plasma, and also (24) reported that given rabbit ochratoxin at A 1 ppm for 60 days led to decrease ALP in their serum levels value.

The decrease in the serum level of ALP may resulted from the decline in phosphorus levels (hypophosphatemia) that resulted from increased renal ions excretion due to kidney damage or due to decrease in phosphate absorption caused by from OTA toxic effect as reported by our histopathology changes noticed in OTA dosed rat kidney in dose dependent manner (25).

Glutathione levels in serum and tissues is one of important biochemical marker for tissue oxidative damage, so any reduction in its normal levels indicate debilitation of glutathione concentration due to its antioxidative effect.Glutathione biosynthesis is not an essential nutrient (meaning it does not have to be obtained via food), since it can be synthesized in the body from the amino acids L-cysteine, L-glutamic acid, and glycine. The sulfhydryl (thiol) group $(\mathrm{SH})$ of cysteine serves as a proton donor and is responsible for the biological activity of glutathione. $(26,27)$.

The decrease in GSH serum levels reported in our study may caused by the proposed mechanism of ochratoxin A (OTA) toxicity that has been found to involve the production of free radicals and consequent oxidative stress.

The mechanism of OTA toxicity is not fully understood, but the proposed mechanism includes inhibition of mitochondrial respiration correlated with a depletion of ATP, inhibition of protein synthesis, and enhanced lipid peroxidation. Furthermore, it is not clear whether OTA carcinogenicity is the result of its direct genotoxic effect or of indirect mechanisms such as induction of cytotoxicity and oxidative damage.

Oxidative damage is caused by free radicals, more specifically reactive oxygen species (ROS) that are continuously produced in normal physiological processes (28). Oxidative stress is defined as the imbalance between ROS production and natural antioxidants in biological systems like glutathione, which leads to the damage of macromolecules such as lipids, proteins, carbohydrates, RNA, and DNA.(29). 
Angela (30) reported that OTA-induced pathology was present at all dose levels administered $(0.25,0.5,1$, and $2 \mathrm{mg} / \mathrm{kg}$ of body wt) to male F344 rats, with a clear increase in severity related to dose. Pathology was restricted to the outer stripe of the outer medulla and consisted of disorganization of the tubule arrangement, frequent apoptotic cells, and abnormally enlarged nuclei scattered through the S3 tubules. Consistent with the histopathology, a dose-dependent increase in the expression of proliferating cell nuclear antigen (PCNA), indicative of cell proliferation, was observed in kidneys, but not in livers of treated animals.

Significant histopathologic changes were found in the kidney and liver tissue of rats treated with $289 \mu \mathrm{g} / \mathrm{kg}$ OTA. There were granular or vacuolated degeneration and necrosis of the liver cells, sinusoidal and central vein dilatation, bile duct proliferation, enlargement of periportal areas with mononuclear cell inflammatory infiltration and mild degree fibrous tissue proliferation, tubular epithelial cells degeneration, necrosis, proliferation and karyomegaly in the epithelial cells nuclei and peritubular and periglomerular lymphocyte infiltration, stromal fibrous tissue proliferation, hyperemic vessels(31).

Ochratoxin A was given by gavage to male rats. Moribund and dead animals were necropsied, and the surviving rats, including the controls, were killed 48 hours after dosing. Many of the principal rats were moribund, or began dying, within 12 to 24 hours after dosing. Lesions suggestive of disseminated intravascular coagulation were seen by light microscopy as early as 12 hours after dosing; fibrin deposits were in the spleen, brain choroid plexus, glomerular capillaries, liver, and heart. Renal tubular nephrosis, hepatic and lymphoid necrosis, and necrotic enteritis with villous atrophy were also seen.

\section{References}

1- El Khoury, André and Atoui, Ali.n .(2010). Ochratoxin A: General Overview and Actual Molecular Status. Toxins., 2. 461-493.

2-Van der Merwe; K. J., Steyn, P. S.; Fourie, L.; Scott, D. B. and Theron, J. J. (1965). Ochratoxin A, a toxic metabolite produced byAspergillus ochraceus Wilh. Nature. 205, 1112-1113.

3- Lindsey, H. (2002). Ochratoxin A may cause testicular cancer. Lancet Oncol., 3, 129-130.

4- Petziner, E. and Ziegler, K. (2000). Ochratoxin A from a toxicological perspective. J. Vet. Pharmacol. Ther., 23, 91-98.

5-Dai, J.; Wright, M. W. and Manderville, R. A. (2003). Ochratoxin A forms a carbon-bonded C8-deoxyguanosine nucleotide adduct: implications for C8 reactivity by a phenolic radical. J Am Chem., Soc., 125, 3716-3717.

6- Maaroufi, K.; Achour, A.; Betbeder, A. M.; Hammami, M.; Ellouz, F.; Creppy, E. E. and Bacha, H. (1995). Foodstuffs and human blood contaminated by the mycotoxin ochratoxin A: correlation with chronic interstitial nephropathy in Tunisia. Arch. Toxicol., 69, 552-558

7- Muller, G.; Rosner, H. and Rohrmann, B. (2003).Effects of the mycotoxin ochratoxin A and some of its metabolites on the human cell line THP-1. Toxicol., 184, 69-82.

8- Walker, R. (2002). Risk assessment of ochratoxin: current views of the European Scientific Committee on Food, the JECFA and the Codex Committee on Food Additives and Contaminants. Adv Exp Med Biol., 504,249-255.

9- Lebrun S, Föllmann W.(2002). Detection of ochratoxin Ainduced DNA damage in MDCK cells by alkaline single cell gel electrophtoresis (comet assay). Arch Toxicol .75:734-41

10- Zepnik ,Herbert; Völkel ,Wolfgang and Dekant,Wolfgang . (2003). Toxicokinetics of the mycotoxin ochratoxin A in F 344 rats after oral administration .Toxicology and applied pharmacol., 192 (1) :36-44.

11- Zhang ,Xiangnan; Saadatmandi ,Christine Boesch ; Lou ,Yijia; Wolffram, Siegfried; Huebbe, Patricia and Rimbach, Gerald.( 2009). Ochratoxin A induces apoptosis in neuronal cells. National center for Biotechno. Inform., 134:771-782. 
12- Ringo, Diana; Chango, Schneider, Yves-Jacques; Larondelle, Yvan . (2010). Toxicokinetics and toxicodynamics of ochratoxin A, an update. chemico-biological interaction , 159:18-46.

13- Hafez, E S E. (1970). Reproduction and breeding techniques for laboratory animals .Lea and febiges , Philadelphia .

14- Reitman, S. and Frankel, S.J. (1957).Acolorimetric method for determination of serum oxaloacetatic acid and pyruvic transaminases. Am. J. Clin. Pathol., 28: 56-63.

15- Belfield, A. and Goldberg, D.M. (1971). Revised assay for serum phenyl phosphatase activity using 4-amino-antipyrine - Enzyme. J. Clin. Path. ,12: 561-573.

16- Burtis, C. and Ashwood, E. (1999).Textbook of clinical chemistry. 3d Ed. London. 2(33): 1145-1150.

17-Lee, G. and Luna, L.G. (1968).Manual of histological staining methods of Armed Forces institutes of pathology. 3rded. Mc Grow-Hill Book Company. New York. Pp: 12-31.

18-Joda, M. (2008).The progressive statistical analysis by using SPSS. $1^{\text {st }}$ edition Churchill livingstone .Edinburgh .Pp.109-12.

19- American Family Physician. (2005).Mildly Elevated Liver Transaminase Levels in the Asymptomatic Patient - March 15, 2005 - American Family Physician". Retrieved 2009-0711.

20-Atroshi, F.; Rizzo, A.; Sankari, S.; Biese, I.; Westermarck, T.; Veijalainen, P.(2000). Liver enzyme activities of rats exposed to ochratoxin A and T-2 toxin with antioxidants. Journal Bulletin of Environmental Contamination and Toxicol., 64 (4): 586-592.

21- Mayo Foundation for Medical Education and Research (MFMER).(2011). Elevated liver enzymes, MayoClinic.com.

22-Jeremy E.Kaslow.(2011).Alkaline phosphatase . Medical Doctors are licensed and regulated by the Medical Board of California .800: 633-2322.

23- Lippoldl ,C. C. ; Stothers, S. C.; Frohlich, A. A.; Boila , R. J. and Marquardt,R. R. (1992). Effects of periodic feeding of diets containing ochratoxin A on the performance and clinical chemistry of pigs from 15 to $50 \mathrm{~kg}$ body weight. Can. J. Anim. Sci., 72: 135-146.

24- Glahn RP, Wideman RF Jr, Evangelisti JW and Huff WE. (1988). Effects of ochratoxin A alone and in combination with citrinin on kidney function of single comb White Leghorn pullets. Poult Sci. 67(7):1034-1042.

25- Sarah D and Corathers, MD. (2006).Focus on Diagnosis: The Alkaline Phosphatase Level: Nuances of a Familiar Test. Pediatrics in Review. 27 (10): 382 -384.

26-Drevet, J. (2006).The antioxidant glutathione peroxidase family and spermatozoa: A complex story.Molecular and Cellular Endocrinol., 250 (1-2): 70-79.

27-Wu, Guoyao; Fang, Yun-Zhong; Yang, Sheng; Lupton, Joanne R.; Turner, Nancy D. (2004). "Glutathione metabolism and its implications for health". The Journal of nutrition 134 (3): 489-92.

28-Dotan Y, Lichtenberg D and Pinchuk I. (2004).Lipid peroxidation cannot be used as a universal criterion of oxidative stress. Prog Lipid Res.3:200-227.

29- Schaaf GJ, Nijmeijer SM, Maas RFM, Roestenberg P,de Groene EM and Fink-Gremmels J. (2002). The role of oxidative stress in the ochratoxin A-mediated toxicity in proximal tubular cells. Biochim Biophys Acta - Mol. Basis Dis. 1588:149-58.

30- Angela, Mally; Wolfgang ,Völkel ; Alexander, Amberg ; Michael ,Kurz ; Paul, Wanek ; Erwin, Eder ; Gordon, Hard and Wolfgang , Dekant .(2005) . Functional, Biochemical, and Pathological Effects of Repeated Oral Administration of Ochratoxin A to Rats. hem. Res. Toxicol., 18 (8):1242-1252.

31- Aydın ,G ; Ōzçelik ,N ; Çiçek ,E and Soyöz ,M .(2003). Istopathologic changes in liver and renal tissues induced by Ochratoxin $a$ and melatonin in rats. Hum Exp Toxicol. 22(7): 383-391. 